\title{
Study Of Albacore Tuna (Thunnus alalunga) Abundance Using Regional Ocean Modeling System (ROMS) Data In Indian Ocean
}

\author{
Dian Novianto a,b*, Takahiro Ozawa c,d, I Wayan Nuarsa a \\ a Graduate Study of Environmental Sciences, Udayana University, Denpasar, Bali 80232, Indonesia \\ ${ }^{b}$ Marine Research Center, Indonesia Ministry of Marine Affairs and Fisheries (MMAF), Jakarta 14430, Indonesia \\ c Graduate School of Science and Engineering, Yamaguchi University, Ube Shi Tokiwadai 2-16-1, 7550092, Japan \\ ${ }^{d}$ Center for Remote Sensing and Ocean Sciences (CReSOS), Udayana University, PB Sudirman Street, Denpasar, \\ Bali 80232, Indonesia \\ * Correspondence: dianovianto78@gmail.com
}

Received: 10 November 2017; Accepted: 30 November 2018; Available online: 1 Desember 2018

\begin{abstract}
First, we analysed alabcore catch data based on time, positions, and layer alabcore caught and ROMS result data monthly climatology data for temperature, salinity. current velocity, and sea surface height for 2005-2008. Then, we analyzed the relationship between catch data and ROMS data by combining the statistical method of regression trogh origin (RTO) and geographic information system (GIS). Three model RTO were generated with the abundance of albacore tuna as a response variable, and temperature, salinity. current velocity, and sea surface height as predictor variables. All of the predictors of temperature, salinity. current velocity, and sea surface height were highly significant $(\mathrm{P}<0.001)$ to the number of albacore tuna. Values of temperature, salinity. current velocity, and sea surface height in albacore tuna preferences ranged from 220 to $230 \mathrm{C}$, 34.79 to $34.84 \mathrm{Psu}, 0.01$ to $0.03 \mathrm{~m} / \mathrm{s}$ and 0.66 to $0.70 \mathrm{~m}$, respectively. Validation of the predicted number ofalbacore tuna with the observed value was significant $(P<0.05, r 2=0.60)$. sea surface height was the most important environmental variable to the number of albacore tuna caught, followed by temperature, salinity and current velocity.
\end{abstract}

Keywords: albacore; abundance; ROMS; Indian Ocean

\section{Introduction}

Albacore (Thunnus alalunga; hereafter ALB) is one of the main target species of the commercial tuna fishery and has a long history of scientific research (Chen et al., 2005). Although albacore tuna has a long history of scientific research and remains the preeminent target species of the commercial tuna fishery, the related literature in the Indian Ocean is scarce in comparison with other oceanic basins like the Atlantic and Pacific Oceans (Nikolic et al., 2014). The geographical distribution of ALB is from $45-50^{\circ} \mathrm{N}$ to $30-40^{\circ} \mathrm{S}$, although it is less abundant in surface waters between $10^{\circ} \mathrm{N}$ and $10^{\circ} \mathrm{S}$ (Collette \& Nauen, 1983). In the Indian Ocean, ALB is distributed mainly in areas south of $10^{\circ} \mathrm{S}$ and it migrates seasonally between north and south areas in the Southern Hemisphere (Chen et al., 2005). In the Indian Ocean, ALB is caught almost exclusively under drifting longline (98\%), with remaining cacthes recorded under purse seines and other gears (IOTC, 2007; Nishida \& Tanaka, 2008).

Cacth of ALB by Indonesian longline fleets operating in Indian Ocean from 2004-2006 was estimated at 9,081 tons by IOTC, while $53.4 \%$ of which was landed at Benoa fishing port (Proctor et al., 2007). Although the Indian Ocean is one of the most productive fishing grounds, and has a long history of tuna exploitation, little is known about the oceanographic conditions affecting the distribution and abundance of ALB. Previous 
studies showed that Temperature is the most important parameter ALB abundance in the Indian Ocean (Lan et al., 2011; Chen et al., 2005). Whereas for other oceanographic parameters have not been too many studied in the Indian Ocean compared to research in the Pacific Ocean. Goñi et al. (2015) used ROMS to investigated the influence of temperature, salinity and trophic parameters on albacore daily catches in the Northeast Atlantic. They found that the thermal stratification seems to have an important effect on Albacore catches.

The habitat is highly influenced by dynamic oceanographic factors, different characteristic of oceanographic variabilities can influence on fish distribution. Changes and variations of oceanographic factors indicate that the abundance of fish in the waters is unlevel (Zainuddin, 2007). Potential fishing grounds are always changing and moving in accordance with the environmental factors. Fish will choose a more suitable habitat for feeding, shelter, reproduction and migration (Palacios et al., 2006). Generally, the fishing activities by the fisherman are only based on repeated experiences as well as gathering information from fellow fishermen. They are often in uncertain about location of the potential fishing grounds. This leads to wastage of money and time, and catches are less than optimal which impact on the income of fishermen.

The first aim of this research is to find out relationship between oceanographic variables from Regional Ocean Modeling System (ROMS) data on albacore tuna abundance in Indian Ocean. ROMS incorporates advanced features and high order numerics, allowing efficient and robust resolution of mesoscale dynamics in the oceanic and coastal domains (ROMS; Shchepetkin and McWilliams, 2005). The model solves the free surface, hydrostatic, primitive equations of the fluid dynamics over variable topography using stretched, terrain-following coordinates in the vertical and orthogonal, curvilinear coordinates in the horizontal (Putra et al., 2009). ROMS have a high accuracy rate that is suitable for investigating vertically Oceanographic conditions so expect to get maximum results in this study.

\section{Materials and Methods}

\subsection{Study Area}

The study location is the range between $09^{\circ}-15^{\circ} \mathrm{S}$ latitude and $110^{\circ}-120^{\circ} \mathrm{E}$ Longitude. The area was selected based on data availability and information ALB fishing operations (Figure 1).

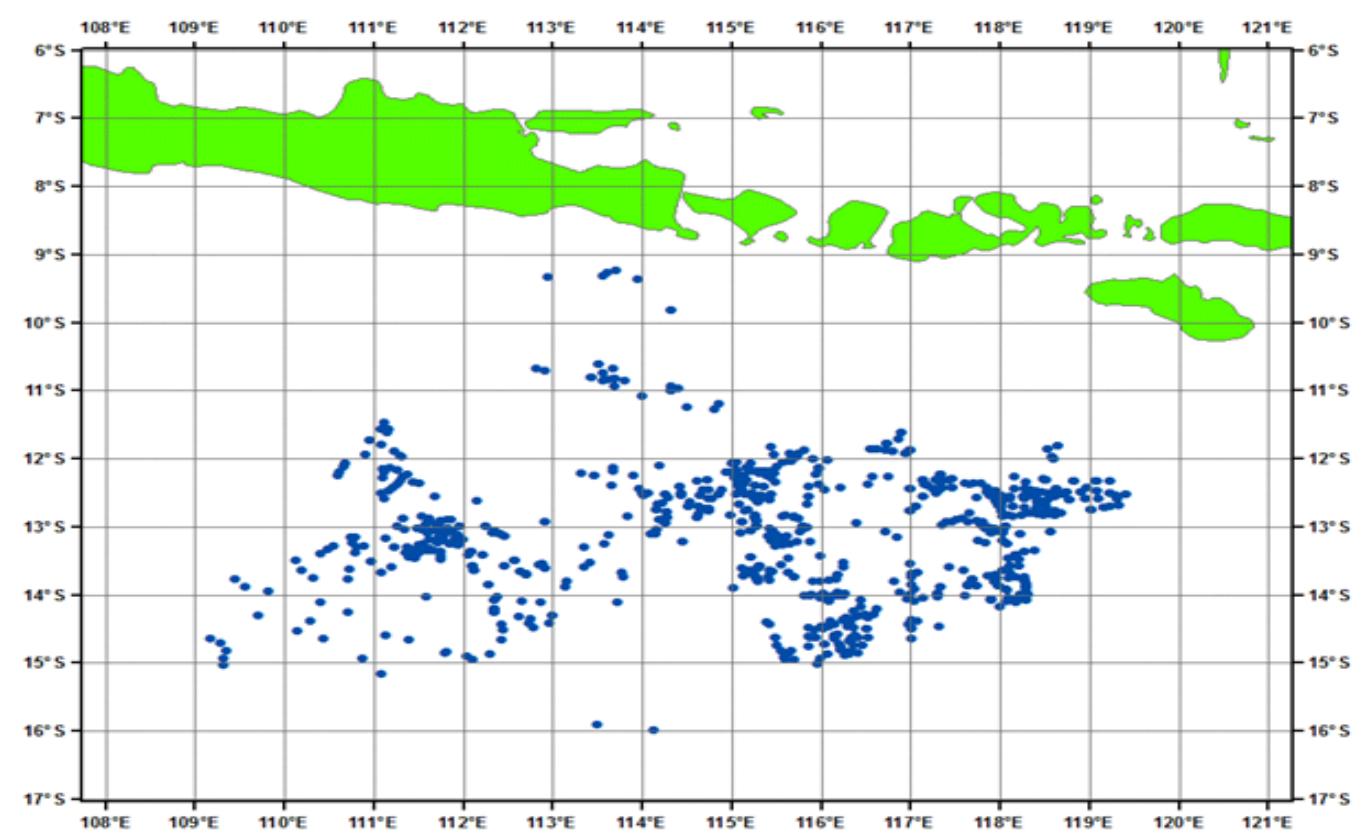

Figure 1. Research location 


\subsection{Analysis Data}

Various variables were analyzed on this research, includes ALB catchment data, in addition oceanographic variables consist of temperature, salinity, current velocity are results from ROMS data (1990-2008) is divided into 6 layers except for the sea surface heigth which were analyzed to examine their influences on ALB tuna data.

\subsubsection{Oceanographic Data}

ROMS data divided into two, the data consist forcing data and boundary condition data. Forcing data using NCEP reanalysis data and boundary condition data use SODA data (Simple Ocean Data Assimilation). ROMS data Spatial resolution is $10 \mathrm{~km}$ for the horizontal and $25 \mathrm{~S}$-coordinate layer vertically. Initial Condition using SODA with updates boundary of each month the data U, V, T, and S, with models running from 1990 to 2008. The model domain of $90^{\circ}-150^{\circ} \mathrm{E}$ and $15^{\circ} \mathrm{S}-15^{\circ} \mathrm{N}$, but in the domain visualization narrowed down to $110^{\circ}-125^{\circ} \mathrm{E}$ and $15^{\circ} \mathrm{S}-8^{\circ} \mathrm{S}$. ROMS data output in netCDF file. Read data processing using Grads software to plot each variable oceanography which used for overlay to each depth position with ALB caught.

\subsubsection{Fish Data}

The fishery data is consisted of daily ALB catchment based number of branch line longline fishing gears, fishing effort and fishing position in latitude and longitude for the period from 2005 to 2009, obtained from scientific observer program RITF (Research Institute for Tuna Fisheries). These data were extracted to obtain geographic information where the ALB were caught, time when the operational catchment and number induvidual ALB which caught on each branch line of longline fishing gears as information on how the depth of ALB caught.

\subsubsection{Hook Depths Estimation}

In the measurement of depth of the hook, there are many factors which affect, among other things: the amount of basket that is used, total length of the main line, length of branch line, length of floatline, the speed of the mainline thrower to speed of vessel, total time for settings and current factor as a correction factor. The depth of the hook can be estimated using the formula Yoshihara (1951) as follows:

$$
D=f l+b l+\frac{1}{2} B K\left\{\sqrt{\left(1+\operatorname{Cotg}^{2} \sigma\right)}-\sqrt{(1-2 j / n)^{2}+\operatorname{Cotg}^{2} \sigma}\right\}
$$

Where :

D : The depth of jth hook (for each basket, the two hooks closest to the floats are both numbered 1 , assuming that branchlines were hung symmetrically),

$\mathrm{fl}$ and $\mathrm{bl} \quad$ : The length of floatline and length of branchline, respectively.

BK : The length of mainline in unit basket,

$\mathrm{n} \quad$ : The number of branchline in unit basket.

j : Number of hooks position

$\sigma \quad:$ The angle between horizontal line and tangential line of the mainline at connecting points of mainline and floatline, and

$$
K=\frac{V k \times T s}{B K \times \sum b}
$$

Where

$K \quad$ : The sagging ratio

$V k \quad:$ Speed of the mainline thrower to speed of vessel (m/hours),

Ts : Setting time, 
$B K \quad$ : The length of mainline in unit basket $(\mathrm{m})$

$\sum b \quad$ : Number of basket in used.

The relationship between the value of $\mathrm{K}, \sigma$ and $\sigma$ Cotg2 can be seen in Table 1 .

Table 1. The relationship between the value of $K, \sigma$ and $\sigma$ Cotg $\sigma$

\begin{tabular}{ccc}
\hline $\mathrm{K}$ & $\sigma(0)$ & $\operatorname{Cotg} 2 \sigma$ \\
\hline 0,902 & 40 & 1,2767 \\
0,847 & 50 & 0,7038 \\
0,769 & 56 & 0,4727 \\
0,725 & 60030 & 0,3300 \\
0,703 & 65 & 0,2077 \\
0,661 & 68 & 0,1630 \\
0,540 & 72 & 0,1331 \\
0,000 & 90 & 0,0000 \\
\hline
\end{tabular}

\subsubsection{Regression Through Origin}

Textbooks rarely discuss RTO other than to caution against dropping the constant term from a regression, on the grounds that imposing any such restriction can only diminish the model's fit to the data. There are, however, circumstances in which RTO is appropriate or even necessary (Eisenhauer, 2003). First, RTO may be unavoidable if transformations of the OLS (ordinary least-squares) model are needed to correct violations of the Gauss-Markov assumptions. Consider, for example, the simple linear regression of $\mathrm{Y}$ on $\mathrm{x}$. The basic linear regression model is given by:

$$
Y i=\beta 0+\beta 1 x i+e i
$$

Where $\beta_{0}$ is the intercept, $\beta_{1}$ is the slope and $e_{i}$ denotes the $i^{\text {th }}$ residual. Lagging observations and taking first differences (i.e. subtracting each observation from its successor) to correct for serial correlation in the errors requires transforming equation (26) into an RTO equation of the form:

$$
Y i-Y i-1=\beta 1(x i-x i-1)+(e i-e i-1)
$$

Alternatively, applying weighted least squares to correct for heteroscedasticity will result in a model with no intercept if the weighting factor $(z)$ is not an independent variable. In that case, $\beta_{0}$ becomes a coefficient and equation (27) is replaced by a multiple linear regression without a constant:

$$
Y i / Z i=\beta 0(1 / Z i)+\beta 1(X i / Z i)+(e i / Z i)
$$

Even without such transformations, however, there are often strong a priori reasons for believing that $\mathrm{Y}=0$ when $\mathrm{X}=0$, and therefore omitting the constant. Final the simple linear RTO model equation is:

$$
Y i=\beta 1 x i+e i
$$

Where $\beta 1$ is the slope and ei denotes the ith residual. Two hypothesis apply to determine linearity of slope were stated below:

$$
\begin{aligned}
& H_{0}: \beta=0 \\
& H_{1}: \beta \neq 0
\end{aligned}
$$


Single parameter t-test was used to test those hypothesis. The t-value resulted from linear regression output calculated by dividing estimated value of predictor variable with it's standard error. The $t$-calculated value compared with with critical t-value from $t$ distribution table with $95 \%$ confidence interval. If the $\mathrm{t}$ - calculated value less then $\mathrm{t}$ distribution table, the $\mathrm{H}_{0}$ rejected. It's mean there is linear relationship between response variable and predictor variable (Vezani, 2005; Zuur et al., 2007).

In addition to linear regression, $\mathrm{p}$-value was used to measure the linear relationship between response variable and predictor variable. $p$-value is the probability that test the statistic test on the observed values (Verzani, 2005). If a p-value is small the test is called statistically significant, as it indicates that the null hypothesis is unlikely to produce more extreme values than the observed one. The p-value range is described on the Table 2.

Table 2. Level of significant for range of p-values (Verzani, 2005)

\begin{tabular}{cc}
\hline$p$-value range & Common description \\
\hline$<0.001$ & extremly significant \\
$0.001-0.01$ & highly significant \\
$0.01-0.05$ & statiscally significant \\
$0.05-0.1$ & could be significant \\
$0.1-1$ & not significant \\
\hline
\end{tabular}

The coefficient determination $\left(\mathrm{R}^{2}\right)$ was used to validate the regression linear model. The higher value of $R^{2}$, the more the model can be explained (Zuur et al., 2007). The $R_{0}{ }^{2}$ calculated from RTO the given equation below:

$$
R_{0}^{2}=\frac{\sum y i^{2}}{\sum y i^{2}}
$$

Where:

$R^{2}$ : Coefficient determination

$\hat{y}:$ fitted y value

$\bar{y}:$ mean of $\mathrm{y}$

When $R^{2}$ close to 1 , most of the variation is explained by the regression line, and when $R^{2}$ close to 0 , regression line does not much explain the variation (Verzani, 2005). All procces statistical using $\mathrm{R}$ software. In order to choose the final linear model equation, the $\mathrm{p}$-value, Akaike information Criteria (AIC), residual deviance explained of the $1 \mathrm{~m}$ outputs were considered. In $\mathrm{R}$ software the criterion used is:

$$
A I C=-2 * \log L+k * e d f
$$

Where $L$ is the likelihood and edf the equivalent degrees of freedom (i.e., the number of free parameters for usual parametric models) of fit. For linear models with unknown scale (i.e., for $\operatorname{lm}$ and aov), $-2 \log L$ is computed from the deviance and uses a different additive constant to logLik and hence AIC.

\section{Results}

\subsection{Vertical Distribution of $A L B$}

ALB fishing ground was mapped base on depth catchment data (Figure 2). Color dots on the image shows position and depth of ALB caught. The data were divided by month during 2005-2009, unfortely there is no data in January and February, this is due to extreme weather conditions causing no ship activity in Benoa port. ALB fishing grounds is mostly done outside the EEZ, because of ALB is high migratory and oceanic spesies. 


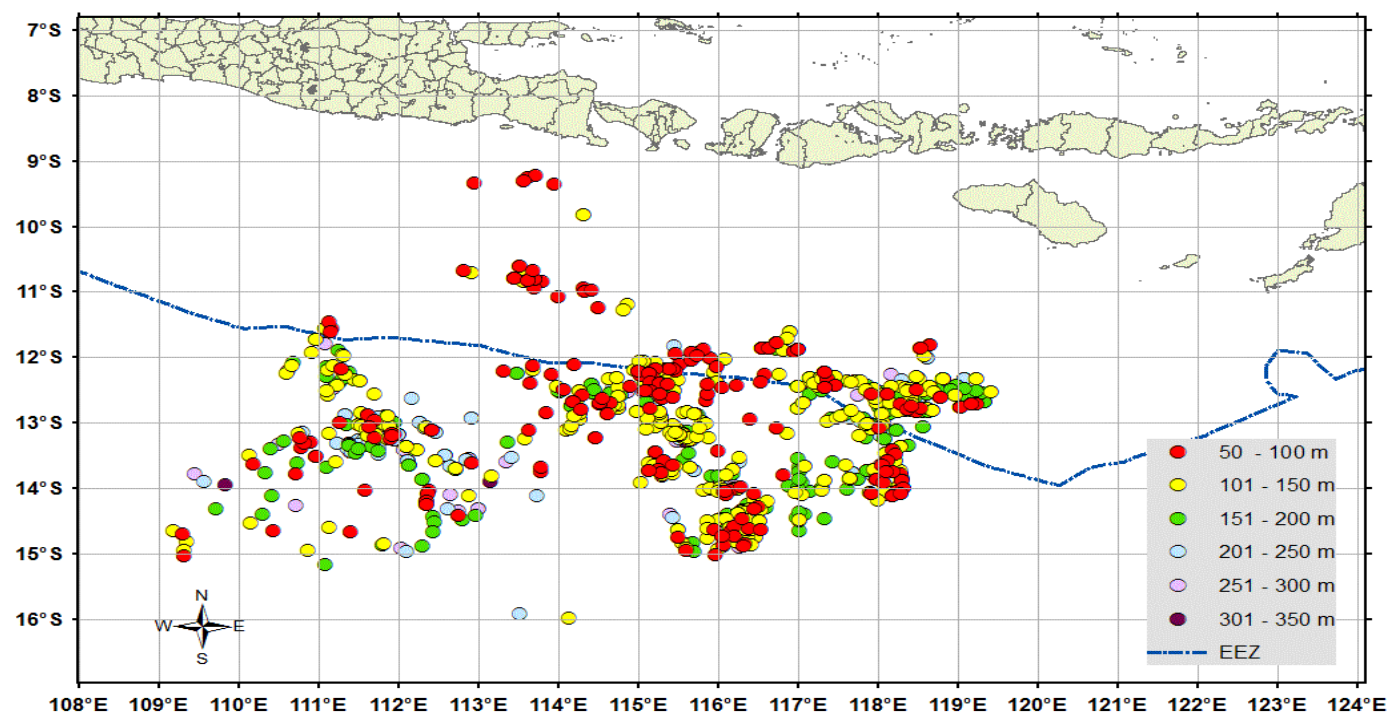

Figure 2. Distributions of ALB caught (without January and February)

Vertical distributions divided into 6 layers of depth of water it was decided based on the depth of fishing gear longline which used for ALB can reach a depth of $450 \mathrm{~m}$. Based on calculation of Yoshihara formula, vertical distributions of ALB from the depths of 50400 meters where ALB mostly were caught at a depth of 101-150 meters and decreased number of catches directly proportional with increasing depths (Figure 3).

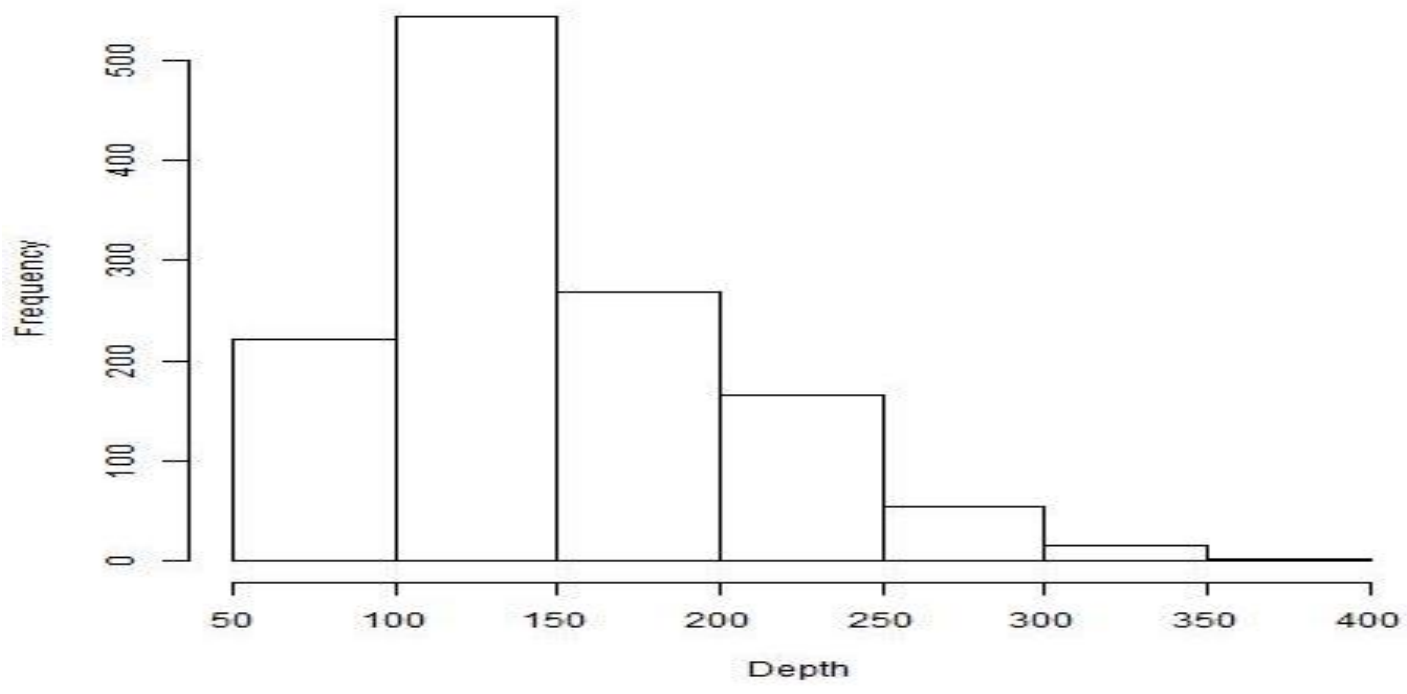

Figure 3. Frequency of ALB catches by the depth of hooks

\subsection{Oceanographic Variabels on ALB Fishing Gorund}

In addition to estimate distribution ALB based on oceanographic preferences during period 2005-2009, frequency value of each oceanographic variable was performed using histogram. The pattern of distributions of ALB caught in the fishing ground indicated that temperature range between $13.28-26.74^{\circ} \mathrm{C}$ during this period (2005-2009). Wherein distribution patterns formed by swimming layer of ALB. There are 6 groups with a temperature range from distribution pattern of ALB, i.e. : $13^{\circ} \mathrm{C} ; 15^{\circ} \mathrm{C} ; 17^{\circ} \mathrm{C} ; 19-20^{\circ} \mathrm{C}$; 22-23 ${ }^{\circ} \mathrm{C}$ and $26^{\circ} \mathrm{C}$ respectively. The percentage of temperature wherein ALB caught i.e. : $23^{\circ} \mathrm{C}(24.45 \%), 22^{\circ} \mathrm{C}(17.43 \%), 19^{\circ} \mathrm{C}(14.20 \%) 26^{\circ} \mathrm{C}(13.56 \%)$ and $17^{\circ} \mathrm{C}(10.41 \%)$ respectively, while the percentage of other temperature below 10\% (Figure 4). 


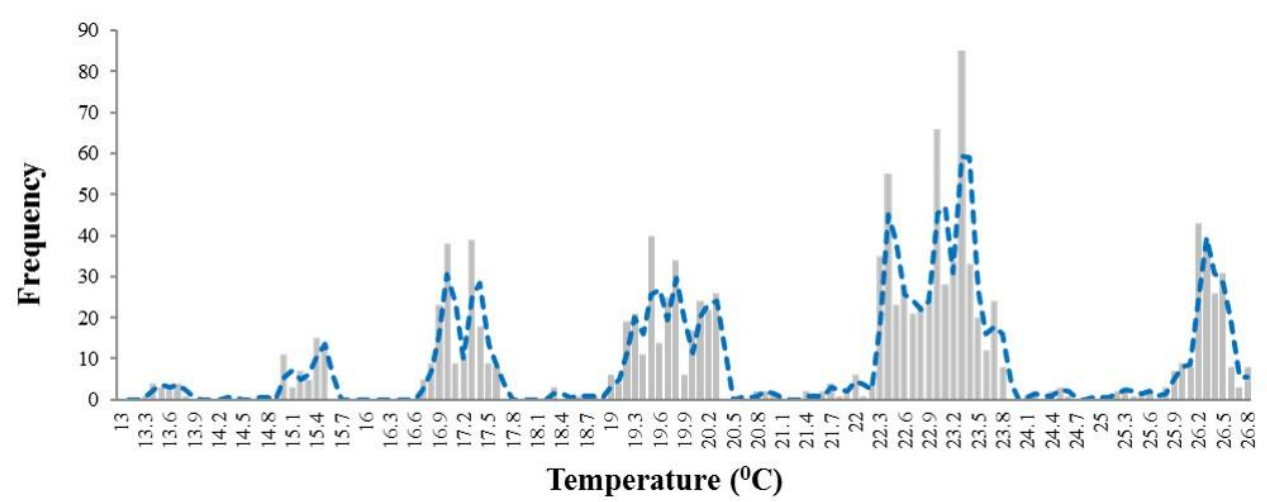

Figure 4. Temperature distributions of ALB caught during 2005-2009 period

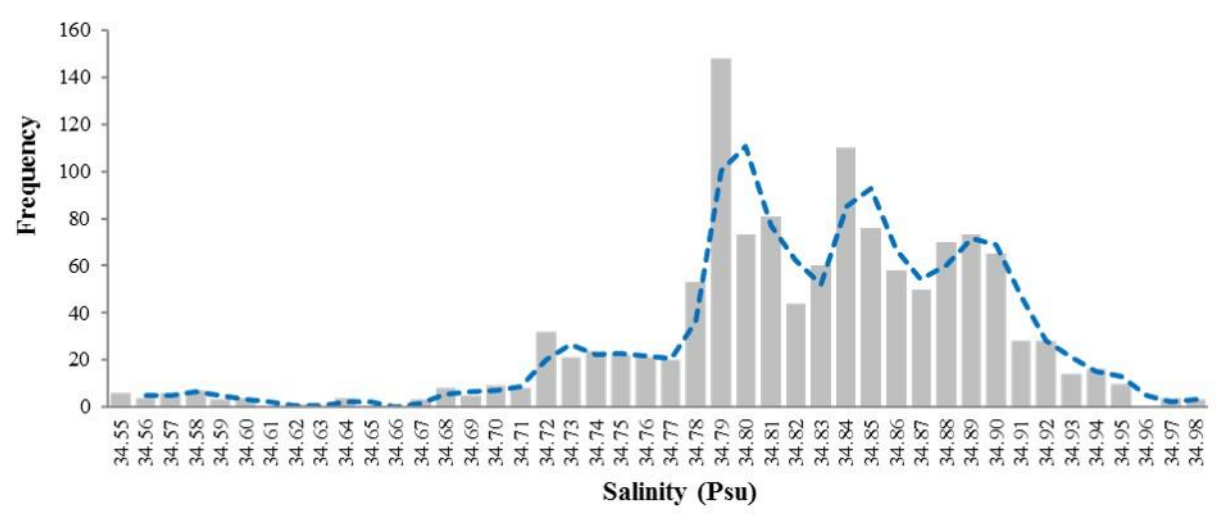

Figure 5. Salinity distributions of ALB caught during 2005-2009 period

Figure 5, showed the pattern of ALB distributions based on Salinity that is not too varied. The range of salinity values at point 34.55 to 34.97 Psu. The range point of salinity showed a very thin difference with a scale 0:01 Psu, wherein ALB mostly caught at salinity range on $34.79-34.98$ Psu. The percentage of salinity wherein ALB caught is $34.79(11.64 \%), 34.84(8.65 \%)$ and $34.81(6.37 \%)$ respectively, while the percentage of other salinity below $6 \%$.

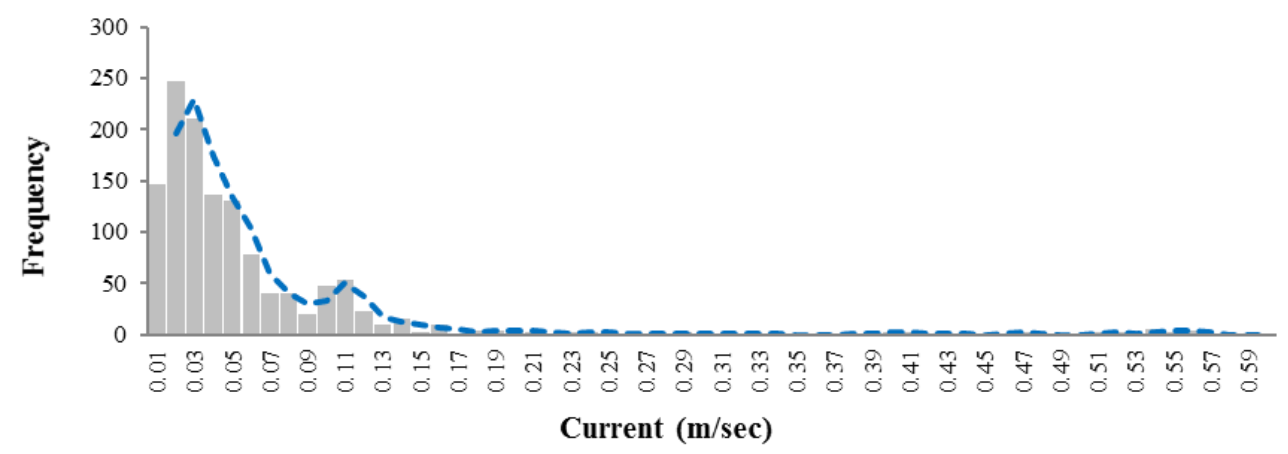

Figure 6. Current velocity distributions of ALB caught during 2005-2009 period

Figure 6, showed current velocity was 0.01 to $0.56 \mathrm{~m} / \mathrm{sec}$. ALB mostly caught with current velocity range average 0.01 to 0.06 . current velocity conditions very low caused the position of fishing grounds quite far from The Indonesian through flow and mostly ALB swimming layer depths occurred on $100-200$ meter. The percentage of current velocity wherein ALB caught is $0.02 \mathrm{~m} / \mathrm{s}(19.46 \%), 0.03 \mathrm{~m} / \mathrm{s}(16.63 \%), 0.01 \mathrm{~m} / \mathrm{s}(11.51$ $\%), 0.04 \mathrm{~m} / \mathrm{s}(10.72 \%)$ and $0.05 \mathrm{~m} / \mathrm{s}(10.24 \%)$ respectively, while the percentage of other current velocity below $6 \%$. 


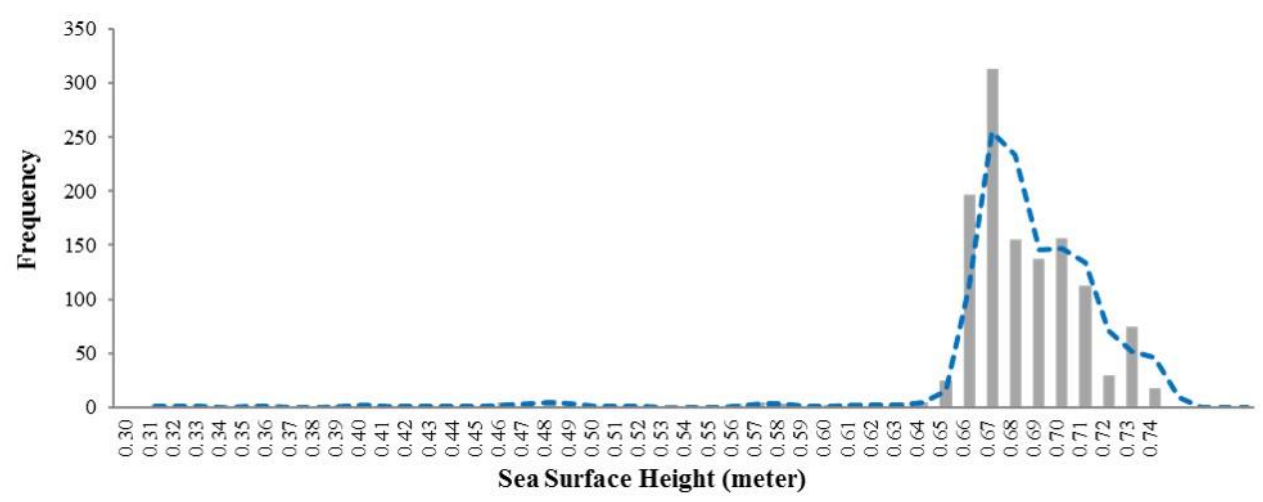

Figure 7. SSH distributions of ALB caught during 2005-2009 period

Figure 7 , showed SSH conditions ALB caught were $0.31-0.74$ meter. The range point of SSH showed a very thin difference with a scale 0:01 meter. ALB mostly caught with SSH range average 0.65 to 0.74 meter. The percentage of SSH wherein ALB caught is $0.67(24.68 \%), 0.66$ (15.54\%), 0.70 (12.30\%), $0.68(12.22 \%)$ and 0.69 (10.80\%) respectively, while the percentage of other SSH below $10 \%$.

\subsection{Linear Regression Result}

Prior to examining the relationship between ALB catches and environmental variables, we examined the relationship between number of ALB caught and each oceanographic variables. The effect of environmental conditions, deduced from linear regression outputs, indicated that environmental variables strongly influenced the numbers of ALB caught.

Table 3. showed list regression model variable, $\mathrm{p}$-value, $\mathrm{t}$ value, and $\mathrm{R}_{0}{ }^{2}$. The predictor variables were highly significant $(\mathrm{P}<0.01)$. Regression model showed that the critical value $t$-value of oceanographic data is 1.66 (significance level is 0.05 , two sided, $\mathrm{df}=67$ ). Based on the t-value, all predictor variable has linear relationship with response variable. The $\mathrm{t}$-value all variables was higher than critical $\mathrm{t}$-value. It is mean, the linear regression of the variable has $\beta \neq 0$.

Table 3. Results of regression model for each parameter

\begin{tabular}{lllll}
\hline Response Variable & Predictor Variables & p-value & t value & R02 \\
\hline Number of ALB & Temperature (0C) & $1.69 \mathrm{E}-14$ & 9.725 & 0.5756 \\
based on depth & SSH (m) & $3.88 \mathrm{E}-13$ & 8.967 & 0.5418 \\
& Salinity (PSU) & $4.32 \mathrm{E}-13$ & 8.94 & 0.5336 \\
& Current (m/s) & $2.46 \mathrm{E}-09$ & 6.867 & 0.4008 \\
\hline
\end{tabular}

\subsection{Model Selection}

Before determining the model to be used in this study, several types of test procedures have been performed to test goodness of fit model. All test procedure performed in $\mathrm{R}$ software. Pairplots used to determine whether there is collinearity (interplay) between oceanographic variables were examined. Collinearity is one of the requirements for regression analysis. Finally, only variable depth, temperature and salinity cannot be used as predictor variable at the same time, so there are only 3 possibilities to establish a regression equation i.e:

$$
\begin{aligned}
& \operatorname{lm}(\text { formula }=\mathrm{ALB} \square \text { Depth }+ \text { Curr }+\mathrm{SSH}-1) \\
& \operatorname{lm}(\text { formula }=\mathrm{ALB} \square \text { Temp }+ \text { Curr }+\mathrm{SSH}-1)
\end{aligned}
$$




$$
\operatorname{lm}(\text { formula }=\mathrm{ALB} \square \mathrm{Sal}+\mathrm{Curr}+\mathrm{SSH}-1)
$$

The Akaike information criterion (AIC) value were used to determine the best model, the best model selected based on Smallest value of AIC. From three model linear regression, model with formula: $\operatorname{lm}($ formula $=A L B \sim$ Depth + Curr $+S S H-1$ ) is the level of the highest goodness of fit with higher $\mathrm{R}_{0}^{2}$ and smaller AIC than other models. The final Regression equation for goodness of fit was:

$$
y=-0.06024 \times \text { Depth }-118.62402 \times \text { Curr }+40.52377 \times S S H
$$

Where :

$$
\begin{array}{ll}
\text { y } & \text { : Number of ALB }(\mathrm{n}) \\
\text { Depth } & \text { : Swimming layer ALB caught }(\mathrm{m}) \\
\text { Curr } & \text { : Current velocity }(\mathrm{m} / \mathrm{s}) \\
\text { SSH } & \text { : Sea Surface Height }(\mathrm{m})
\end{array}
$$

\subsection{Model Validation}

Model validations were showed on Figure 8. Residual vs Fitted which has better than other predictor variables which equally spread residuals around a horizontal line without distinct patterns, that is indicated regression line has explain higher linear relationships. Normal Q-Q used checks how closely the data follow a normal distribution. all data has residuals follow a straight line well so that it can be said the assumption of normality is fulfilled. Scale-Location, this plot shows if residuals are spread equally along the ranges of predictors. This graph used to check the assumption of equal variance (homoscedasticity). from all model the residuals appear randomly spread. It's good pattern when horizontal line with equally (randomly) spread points. Residual vs Leverage, this plot helps us to find influential cases if any. Not all outliers are influential in linear regression analysis (whatever outliers mean). Even though data have extreme values, they might not be influential to determine a regression line. That means, the results wouldn't be much different if we either include or exclude them from analysis. They follow the trend in the majority of cases and they don't really matter; they are not influential. On the other hand, some cases could be very influential even if they look to be within a reasonable range of the values. They could be extreme cases against a regression line and can alter the results if we exclude them from analysis. Another way to put it is that they don't get along with the trend in the majority of the cases. In this graph there is no influential case, or cases in each model, caused can barely see Cook's distance lines (a red dashed line) because all cases are well inside of the Cook's distance lines.
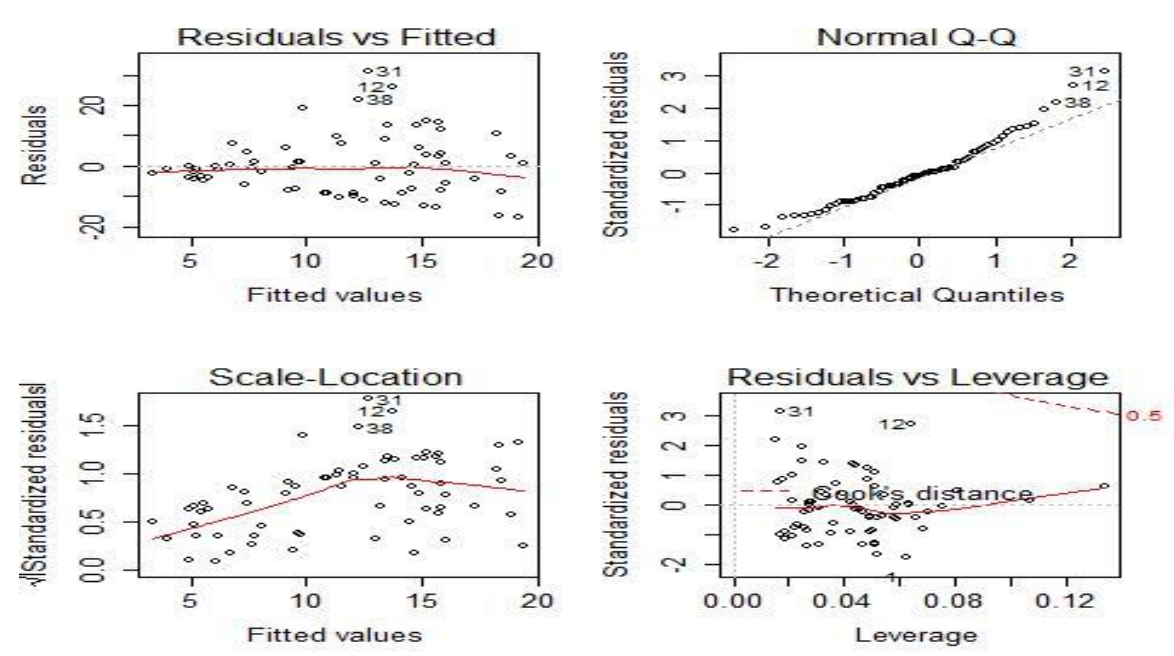

Figure 8. Model validations linear regression 


\section{Discussion}

Fishing ground of ALB mostly done outside the EEZ, this was due to ALB is high migratory and oceanic species and the same distribution each month (Figure 2). Wudianto et al. (2003), stated fishing ground longliners from Cilacap and Benoa port are South central of Java island between $108^{\circ}-118^{\circ} \mathrm{E}$ and $8^{\circ}-22^{\circ} \mathrm{S}$ and fishing operation of longliners $(>70 \%)$ was mostly outside the EEZ of Indonesia. There are two zones of longliners fishing ground base on Benoa port position, ie the zone in the southeastern (south and east) and the zone of southwestern (south and west), intensity of longliners more focused operating in the area southwestern of the Benoa port wherein this area is a potential fishing ground for frozen tuna fleet (Novianto et al. 2010).

Hendiarti et al. (2005) concluded that the "pelagic fish season" develops during the southeast monsoon where maximum and minimum peaks during Jun.-Sep. and November - January respectively. Furthermore, Susanto \& Mara (2005) stated during the southeast monsoon (April to October), Southeasterly wind from Australia generates upwelling, bringing cooler waters and increased nutrients to the surface along the southern coasts of Java and Sumatra. Conditions are reversed during the northwest monsoon (October to April).

The results showed southeast monsoon (June to August) catch data showed that the abundance of ALB was higher rather than in another monsoons. This phenomenon allegedly related with occurrence of upwelling in this region. This result was similar with Lan et al. (2011) indicated that the major fishing period in indian ocean is winter (June to September), and the high CPUEs occur in this period, while low CPUEs occur in summer (March to May), meanwhile Conand et al. (2007) revealed that in the Reunion Island part of West Indian ocean, peak seasons ALB fishing occurred in November-January (transitional warming season). On different location, Briand et al. (2011), revealed that a large part of ALB CPUE variability can be explained by seasonal, interannual and spatial variation of the habitat.

Swimming layer is one of the important factor to get maximum cacthes, especially on tuna longline effort. ALB, being negatively buoyant in seawater, must swim continuously to maintain their position in the water column (Dotson, 1976). Based on spatial distribution analysis ALB mostly were found in the depth around $100-150 \mathrm{~m}$ (Figure 5.2). This result was almost similar with Domokos et al. (2007), who was mentioned that ALB spend most of their time between 150 and $250 \mathrm{~m}$ during the daytime and between 0 and $200 \mathrm{~m}$ during the night-time, at depths coinciding with those of small local maxima in micronekton biomass whose backscattering properties are consistent with those of the preferred prey of ALB. Arrizabalaga et al. (2015) stated ALB preference and tolerance ranges extend to about $200 \mathrm{~m}$. Meanwhile Nugraha \& Triharyuni (2009) mentioned that ALB in Indian Ocean were caught in depth of 150 - $199.9 \mathrm{~m}$, were also comparable to those in Sukresno et al. (2014) in the same region concluded ALB were found in the depth around $150 \mathrm{~m}$. Williams et al. (2014) revealed evidence that ALB tagged in the two tropical locations rarely occupied water shallower than $100 \mathrm{~m}$ during the day, remaining below the MLD, with fish spending most (New Caledonia: 80\%, Tonga: 88\%) of the time between 150 and $250 \mathrm{~m}$ and $200-350 \mathrm{~m}$, respectively and spent most (New Caledonia: 56\%, Tonga: 63\%) of the night-time between 50 and $150 \mathrm{~m}$ and Maximum depths recorded by ALB tagged in New Caledonian, Tongan and New Zealand waters were $372 \mathrm{~m}, 409 \mathrm{~m}$ and $250 \mathrm{~m}$, respectively.

Analysis Sub-surface sea water temperature showed fluctuates seasonally. Monthly average of sub-surface temperature was found tend to vary from January to December. $\mathrm{Qu}$ et al. (2005), who had stated that sub-surface temperature in Indian Ocean was influenced by monsoon. In addition to sub-surface temperature, the range of sub-surface temperature during northwest monsoon in the depth around 51-100 m was about 29.20 ${ }^{\circ} \mathrm{C}$, while in southeast monsoon was about $27.94{ }^{\circ} \mathrm{C}$. Temporal distribution of sub-surface temperature in Indian Ocean part South of Java was warmer in northwest monsoon than in southeast monsoon (Sukresno et al., 2014; Hartoko, 2010). Variability oceanographic condition maps were shown on Appendix 2.

This study shows that most caught ALB in temperature conditions ranging between $22-23{ }^{\circ} \mathrm{C}$ with the proportion of total $532(41.82 \%)$ of the total 1272 ALB caught. Different result from Sukresno et al. (2014) in the same region concluded ALB were found with 
optimum temperature between $17^{0}-21^{\circ} \mathrm{C}$, where ALB avoids waters below $14^{\circ} \mathrm{C}$ (Arrizabalaga et al., 2015). Meanwhile Zainuddin et al, (2011) in the western North Pacific Ocean indicated that the highest concentrations of ALB were found in water of 18.5 $21.5^{\circ} \mathrm{C}$ and tended to be centered at $20^{\circ} \mathrm{C}$. Williams et al. (2014) found evidence that ALB tagged in New Zealand waters primarily spent most (85-97\%) of their time in water $17-20^{\circ} \mathrm{C}$ both during the day and during the night, and in the two tropical locations, ALB spent most of their time (New Caledonia: 80\%, Tonga: 98\%) at night between 22 and $26{ }^{\circ} \mathrm{C}$, with the fish tagged in Tongan waters occupying mostly cooler waters $\left(16-21{ }^{\circ} \mathrm{C}\right)$ during the day than those ALB tagged off New Caledonia $\left(19-23^{\circ} \mathrm{C}\right)$.

The salinity of the former is less than that of the latter, with range of the ALB closely correlated to catch rate is from 34.68 to 34.95 PSU, and the range more closely correlated to catch rate is from 34.72 to 34.92 PSU with the proportion of total 1,157 (90.95\%) of the total 1272 ALB caught. This result was almost similar with Roberts (1980), stated that most ALB were caught either in subtropical water or in the Subtropical Convergence Zone with range of salinities 34.6 - $35.4 \%$ in New Zealand water. Different result from Arrizabalaga et al. (2015) which states that ALB and skipjack showed clearly defined preferred salinity ranges, at around 36-37 PSU. Chen et al. (2005) concluded that Higher CPUE of ALB occured in Salinity 35.32 PSU, and concentration of immature ALB matched the higher salinity zones, yet they could not conclude from their observations whether the current system or the salinity itself caused the coincidence.

ALB is a temperate to subtropical species with highest CPUEs between $20^{\circ}-40^{\circ}$ of each hemisphere (Arrizabalaga et al., 2015). The distribution pattern of ALB in the Indian Ocean for imature and mature ALB tuna based north-south seasonal migration, within $10^{\circ}$ and $30^{\circ} \mathrm{S}$, the separation of mature, spawning, and immature ALB life history stages roughly coincided with the boundaries of the three oceanic current systems in the Indian Ocean (Chen et al., 2005). The favourable ALB fishing grounds are located along the oceanic frontal region, higher hook-rate of ALB were found around or adjacent to the oceanic fronts, i.e. around the water boundary of the equatorial countercurrent and south equatorial current; near the water boundary (convergence) between the south equatorial current and the Indian Ocean central water; near the subtropical convergence in the southern hemisphere. (Uda \& Nakamura, 1973). Xu et al. (2013), revealed in the open ocean, high CPUE ALB is related with a small to moderate GCM (absolute values are $<0.15 \mathrm{~m} \cdot \mathrm{s}-1)$. Current velocity in the area ALB caught very low, mostly ALB caught were current velocity on $0.02 \mathrm{~m} / \mathrm{s}$ with the proportion of total $248(19.46 \%)$ of the total 1272 ALB caught. Allegedly at the ALB fishing ground area there are two types of current i.e, South Equatorial current (SEC) and Rossby Waves (RW) that affect the abundance of ALB. The waves affect the thermocline depth, and hence the ocean's temperature profile, as well as the sea surface height and can either raise or lower the thermocline, leading to a decrease or in crease respectively in the sea surface height (Gnanaseelan et al., 2004).

Tropical tunas, as well as ALB, prefer slightly negative or positive values of SSH (Arrizabalaga et al., 2015). According to Xu et al. (2013), in the open ocean, SSH anomaly is an important indicator of ALB habitat. Negative SSH anomaly is associated with cyclonic eddies and divergent upper ocean waters. Under these conditions, cool and nutrient rich waters may be upwelled from deeper ocean as compensation to the divergent surface layer. These upwelling eddies are areas of increased productivity in the open ocean and may attract various prey sources for ALB. These studies show that SSH was more important than temperature, salinity or current in the study area. Based on goodness fit multiple regression model $\mathrm{SSH}$ having the highest t-value in all models with higher significance level than other predictor variables. ALB mostly caught with SSH range average 0.65 to 0.74 meter. The percentage of SSH wherein albakor tuna caught were occurred on the boundary $0.67 \mathrm{~m}$ with the proportion of total $314(24.68 \%)$ of the total 1272 ALB caught.

\section{References}

Arrizabalaga, H., Dufour, F., Kell, L., Merino, G., Ibaibarriaga, L., Chust, G., Irigoien, X., Santiago, J., Murua, H., Fraile, I., Chifflet, M., Goikoetxea, N., Sagarminaga, Y., Aumont, O., Bopp, L., Herrera, M., Fromentin, J. M., \& Bonhomeau, S. (2015). Global habitat preferences of commercially valuable tuna. Deep Sea Research Part II: Topical Studies in Oceanography, 113, 102-112. 
Briand, K., Molony, B., \& Lehodey, P. (2011). A study on the variability of albacore (Thunnus alalunga) longline catch rates in the southwest Pacific Ocean. Fisheries Oceanography, 20(6), 517-529.

Chen, I. C., Lee, P. F., \& Tzeng, W. N. (2005). Distribution of albacore (Thunnus alalunga) in the Indian Ocean and its relation to environmental factors. Fisheries Oceanography, 14(1), 71-80.

Collette, B. B., \& Nauen, C. E. (1983). FAO species catalogue. Volume 2. Scombrids of the world. An annotated and illustrated catalogue of tunas, mackerels, bonitos and related species known to date. Rome, Italy: Food and Agriculture Organization.

Conand, F., Marsac, F., Tessier, E., \& Conand, C. (2008). A ten-year period of daily sea surface temperature at a coastal station in Reunion Island, Indian Ocean (July 1993-April 2004): patterns of variability and biological responses. Western Indian Ocean Journal of Marine Science, 6(1), 1-16.

Domokos, R., Seki, M. P., Polovina, J. J., \& Hawn, D. R. (2007). Oceanographic investigation of the American Samoa albacore (Thunnus alalunga) habitat and longline fishing grounds. Fisheries Oceanography, 16(6), 555-572.

Dotson, R. C. (1976). Minimum swimming speed of albacore, Thunnus alalunga. Fishery Bulletin, 74(4), 955-960.

Eisenhauer, J. G. (2003). Regression through the origin. Teaching statistics, 25(3), 76-80.

Gnanaseelan, C., Vaid, B. H., Polito, P. S., \& Salvekar, P. S. (2004). Interannual variability of Kelvin and Rossby waves in the Indian Ocean from Topex/Poseidon altimetry data. Research Report. Maharashtra, India: Indian Institute of Tropical Meteorology.

Goñi, N., Didouan, C., Arrizabalaga, H., Chifflet, M., Arregui, I., Goikoetxea, N., \& Santiago, J. (2015). Effect of oceanographic parameters on daily albacore catches in the Northeast Atlantic. Deep Sea Research Part II: Topical Studies in Oceanography, 113, 73-80.

Hartoko, A. (2010). Spatial Distribution Of Thunnus. sp, Vertical And Horizontal Sub-Surface Multilayer Temperature Profiles Of In-Situ Agro Float Data In Indian Ocean. Journal of Coastal Development, 14(1), 61-74.

Hendiarti, N., Aldrian, E., Amri, K., Andiastuti, R., Sachoemar, S. I., \& Wahyono, I. B. (2005). Seasonal variation of pelagic fish catch around Java. Oceanography, 18(4), 112-123.

IOTC. (2007). Executive summaries of the status of the major Indian Ocean tunas and billfish (albacore, bigeye, yellowfin, skipjack, and swordfish). Executive summary of the status of the albacore tuna resource. IOTC-2007-SC-03 [E]. 46 pp.

Lan, K. W., Kawamura, H., Lee, M. A., Lu, H. J., Shimada, T., Hosoda, K., \& Sakaida, F. (2012). Relationship between albacore (Thunnus alalunga) fishing grounds in the Indian Ocean and the thermal environment revealed by cloud-free microwave sea surface temperature. Fisheries research, 113(1), 1-7.

Nishida, T., \& Tanaka, M. (2008). General reviews of Indian Ocean albacore (Thunnus alalunga). In Working Party on Temperate Tuna (WPTmT2). Bangkok, Thailand, 1 November 2008 (pp. 1-8).

Nikolic, N., Fonteneau, A., Hoarau, L., Morandeau, G., Puech, A., \& Bourjea, J. (2014). Short review on biology, structure, and migration of Thunnus alalunga in the Indian Ocean. In Working Party on Temperate Tuna (WPTmT5). Busan, Korea, 13,24\&28 July 2014 (pp. 1-15).

Novianto, D., Barata, A., \& Bahtiar, A. (2010). Efektivitas Tali Cucut Sebagai Alat Tambahan pada Pengoperasian Rawai Tuna dalam Penangkapan Cucut. Jurnal Penelitian Perikanan Indonesia, 16(3), 251-258.

Nugraha, B. (2009). Pengaruh suhu dan kedalaman mata pancing rawai tuna (tuna long line) terhadap hasil tangkapan tuna di samudera hindia. Jurnal Penelitian Perikanan Indonesia, 15(3), 239-247.

Putra, I. D. N. N., Osawa, T., \& Arthana, I. W. (2009). Study of ocean circulation in Indonesian archipelago sea using three dimensional ocean model. ECOTROPHIC, 4(2), 92-96.

Palacios, D. M., Bograd, S. J., Foley, D. G., \& Schwing, F. B. (2006). Oceanographic characteristics of biological hot spots in the North Pacific: a remote sensing perspective. Deep Sea Research Part II: Topical Studies in Oceanography, 53(3-4), 250-269.

Proctor, C. H., Andamari, R., Retnowati, D., Prisantoso, B. I., Poisson, F., Herrera, M. \&Fujiwara, S. (2007). The cacth of SBT by the Indonesian longline fishery operating out of Benoa, Bali in 2006. In CCSBT $8^{\text {th }}$ Meeting of the Stock Assessment Group and 12th Meeting of the Extended Scientific Committee. Hobart, Australia, 4-8 September 2007 and 10-14 September 2007.

Qu, T., Du, Y., Strachan, J., Meyers, G., \& Slingo, J. (2005). Sea surface temperature and its variability. Oceanography, 18(4), 50-61.

Roberts, P. E. (1980). Surface distribution of albacore tuna, Thunnus alalunga Bonnaterre, in relation to the Subtropical Convergence Zone east of New Zealand. New Zealand journal of marine and freshwater research, 14(4), 373-380. 
Shchepetkin, A. F., \& McWilliams, J. C. (2005). The Regional Oceanic Modeling System (ROMS): A split-explicit, free-surface, topography-following-coordinates oceanic model. Ocean Modelling, $\mathbf{9}$, 347-404.

Sukresno, B., Hartoko, A., \& Sulistyo, B. (2015). Empirical Cumulative Distribution Function (ECDF) Analysis of Thunnus. sp Using ARGO Float Sub-surface Multilayer Temperature Data in Indian Ocean South of Java. Procedia Environmental Sciences, 23, 358-367.

Susanto, R. D. \& Marra, J. (2005). Effect of the 1997/98 El Nino on Cholorophyll a Variability Along the Southern Coast of Java and Sumatra. Oceanography, 18(4), 124-127.

Uda, M., Nakamura, Y. (1973). Hydrography in relation to tuna fisheries in the Indian ocean. MBAI Special Publication dedicated to Dr. NK Panikkar, (1), 276-292.

Verzani, J. (2005). Using R for introductory Statistic. New York, USA: Chapman and Hall/CRC Press.

Williams, A. J., Allain, V., Nicol, S. J., Evans, K. J., Hoyle, S. D., Dupoux, C., Vourey, E., \& Dubosc, J. (2015). Vertical behavior and diet of albacore tuna (Thunnus alalunga) vary with latitude in the South Pacific Ocean. Deep Sea Research Part II: Topical Studies in Oceanography, 113, 154169.

Wudianto, W., Wagiyo, K., \& Wibowo, B. (2017). Sebaran daerah penangkapan ikan tuna di Samudera Hindia. Jurnal Penelitian Perikanan Indonesia, 9(7), 19-27.

Xu. Y., Teo, S. L. H., \& Holmes, J. (2013). Environmental Influences on Albacore Tuna (Thunnus alalunga) Distribution in the Coastal and Open Oceans of the Northeast Pacific: Preliminary Results from Boosted Regression Trees Models. In ISC Albacore Working Group Meeting. Shanghai, China, 19-25 March 2013 (pp. 1-17).

Yoshihara, T. (1951). Distribution of fishes caught by the long line II. Vertical distribution. Bulletin of the Japanese Society of Scientific Fisheries, 16(8), 370-374.

Zainuddin, M. (2007). Pemetaan daerah potensial penangkapan ikan kembung lelaki (Rastrelliger kanagurta) di perairan kabupaten Bantaeng, Sulawesi Selatan (Mapping of potential fishing grounds of Rastrelliger kanagurta in Bantaeng waters, South Sulawesi). Jurnal Sains dan Teknologi, $\mathbf{7}(2)$, 57-64.

Zainuddin, M., Saitoh, K and Saitoh, S.-I. 2011. Application of satellite microwave remote sensing data to simulate migration pattern of albacore tuna. International Journal of Remote Sensing and Earth Sciences Vol. 8: 49-56.

Zainuddin, M., Saitoh, K., \& Saitoh, S. I. (2011). Application of Satellite Microwave Remote Sensing Data to Simulate Migration Pattern of Albacore Tuna. International Journal of Remote Sensing and Earth Sciences (IJReSES), 8(1), 49-56.

Zuur, A. F., Ieno, E. N., \& Smith, G. M. (2007). Analysing Ecological Data. New York, USA: Springer.

Zuur, A., Ieno, E. N., Walker, N., Saveliev, A. A., \& Smith, G. M. (2009). Mixed effects models and extensions in ecology with $R$. New York, USA: Springer.

(C) 2018 by the authors; licensee Udayana University, Indonesia. This article is an open access article distributed under the terms and conditions of the Creative Commons Attribution (CC-BY) license (http://creativecommons.org/licenses/by/4.0/). 